\title{
INVESTIGAÇÃO ESPACIAL: HABITAÇÃO DE INTERESSE SOCIAL E GERAÇÃO DA URBANIDADE CONTEMPORÂNEA
}

INVESTIGACIÓN ESPACIAL: VIVIENDA DE INTERÉS SOCIAL Y GENERACIÓN DE LA URBANIDAD CONTEMPORÁNEA

\section{SPATIAL INVESTIGATION: SOCIAL INTEREST HOUSING AND GENERATING CONTEMPORARY URBANITY}

\section{CONSTANTINOU, ELIANE}

Dra., Prof. Associada UFRGS, eliane.constantinou@yahoo.com.br

\author{
MACHADO, LETÍCIA BETTIO \\ Graduanda em AU/UFRGS, leticiabettiom@gmail.com
}

\section{RODRIGUES, ADRIANA LUCKEI}

Graduanda em AU/UFRGS, adriana_luckei@hotmail.com

\section{RESUMO}

Este trabalho apresenta a produção parcial da pesquisa Habitação de Interesse Social: interação entre escala arquitetônica e urbana, que objetiva investigar a produção de projetos de Habitação de Interesse Social Contemporânea, realizada através de concursos e/ou parcerias público privadas. A seleção dos projetos foi realizada a partir de um conjunto amostral de vinte e cinco escritórios eleitos em 2010 como a "nova geração da arquitetura brasileira". Neste estudo analisa-se as propostas desenvolvidas pelos escritórios Arquitetos Associados, Yuri Vital - propostas independentes de habitação horizontal - e os escritórios UNA Arquitetos e Grupo SP - propostas verticalizadas para o concurso Habita Sampa. As discrepâncias do arranjo formal das unidades habitacionais, bem como suas relações com os espaços condominiais e público sugerem percepções ambientais distintas. Analisar, comparativamente, como as tipologias habitacionais respondem aos problemas de projeto impostos por distintos contextos, e inferir a respeito da potencialidade de socialização gerada a partir das diferentes configurações espaciais representam o objetivo central desta investigação. A análise se desenvolve a partir de pesquisa bibliográfica, documental e análise gráfico-textual gerada através do redesenho dos projetos e da simulação de percursos a partir dos 3D gerados. Como resultado deste estudo, foram identificados padrões de urbanidade, habitabilidade e estratégias humanizadoras de acordo com as diferentes tipologias. Finalizando, esta pesquisa tem por intuito entender, através da investigação espacial, recursos de projeto que potencializem percepções positivas no sentido de lugar para os usuários.

PALAVRAS-CHAVE: habitação de interesse social; urbanidade; habitabilidade; estratégias humanizadoras.

\section{RESUMEN}

Este trabajo presenta una producción parcial de la investigación Vivienda de Interés Social: interacción entre escala arquitectónica y urbana, que tiene el objetivo de investigar la producción de proyectos de Vivienda de Interés Social Contemporánea, realizada a través de concursos o asociaciones público-privadas. Seleccionamos los proyectos a partir de un muestreo de veinte y cinco oficinas elegidas en 2010 como la "nueva generación de la arquitectura brasileña". Este estudio analiza las propuestas desarrolladas por las oficinas Arquitetos Associados, Yuri Vital - propuestas independientes de vivienda horizontal - y las oficinas UNA Arquitetos y Grupo SP - propuestas verticales para el concurso Habita Sampa. Las discrepancias de la disposición formal de las unidades habitacionales, asi como sus relaciones con los espacios del condominio y público sugieren percepciones diferentes del ambiente. Analizar comparativamente de qué manera las tipologías habitacionales reaccionan a los problemas del proyecto establecidos por distintos contextos e inferir acerca de la potencialidad de sociabilización provocada por las diferentes configuraciones espaciales representan el objetivo principal de esta investigación. El análisis se desarrolla a partir de búsqueda bibliográfica, documental y análisis gráfico-textual producido por medio del rediseño de los proyectos y de la simulación de recorridos a partir de los 3D generados. El resultado de este estudio fue identificar patrones de urbanidad, habitabilidad y estrategias humanizadoras según las diferentes tipologías. Por fin, esta investigación se propone a comprender, a través de la investigación espacial, recursos de proyecto que potencien percepciones positivas en el sentido de lugar para los usuarios. PALABRAS CLAVE: vivienda de interés social; urbanidad; habitabilidad; estrategias humanizadoras.

\section{ABSTRACT}

This paper presents the partial production of the Research Social Interest Housing: interaction between architectural and urban scale, which aims to investigate the production of Contemporary Social Housing Projects, carried out through contests and /or public private partnerships. The selection of the projects was brought in from a sample set of twenty-five offices elected in 2010 as the "new generation of Brazilian architecture". This study analyzes the proposals developed by the offices Arquitetos Associados, Yuri Vital - independent projects for horizontal housing - and the offices UNA Arquitetos and Grupo SP - vertical projects for the Habita Sampa contest. The discrepancies in the formal arrangement of the housing units, as well as their relationship with the condominium and public spaces, suggest different environmental perceptions. Analyzing comparatively how housing typologies respond to the design problems imposed by different contexts, and inferring about the potentiality of socialization generated from the different spatial configurations represent the central objective of this investigation. The analysis was develop by bibliographical research, documentary and graphic-textual analysis generated through the redesign of the projects and the simulation of paths from the generated $3 D$ 
images. As a result of this study, patterns of urbanity, habitability and humanizing strategies were identified according to the different typologies. Finally, this research intends to understand, through the spatial investigation, project resources that potentialize positive perceptions in the sense of place for the users.

KEYWORDS: social interest housing; urbanity; habitability; humanizing strategies.

\section{INTRODUÇÃO}

A pesquisa 'Habitação de Interesse Social: Interação entre escala Arquitetônica e Urbana', tem como tema de estudo a análise de soluções projetuais realizadas para concursos e/ou parcerias público privadas. Os projetos são escolhidos a partir da publicação realizada pela revista AU-Arquitetura e Urbanismo (Editora PINI), que indica 25 escritórios como a "Nova Geração da Arquitetura Contemporânea Brasileira". O objetivo da investigação é desenvolver uma análise comparativa dos projetos de habitação social de tipologia horizontal - entre os escritórios Arquitetos Associados e Yuri Vital - e tipologia vertical - entre os escritórios UNA Arquitetos e Grupo SP. Dessa forma, infere-se a respeito dos possíveis espaços de sociabilização gerados a partir da implantação desses projetos no contexto urbano, simulando os percursos dos pedestres e o desempenho espacial da edificação, utilizando recursos gráficos de redesenho modelos virtuais em 3D.

O escritório Arquitetos Associados foi formado no ano de 1995, sediado em Belo Horizonte, Minas Gerais, e tem a tradição da arquitetura moderna brasileira como ponto de partida. Através da busca de soluções adequadas para os problemas contemporâneos da arquitetura e das cidades, aborda a ampliação da vida útil dos edifícios e busca por adaptação e flexibilidade. O projeto Ipê-Amarelo ficou na colocação prêmio exaequo na Premiação IAB-SP de 2004. O escritório Yuri Vital, fundado em 2006, é conceituado por projetos que pretendem aliar qualidade funcional e estética à simplicidade e baixo custo. Possui um histórico de participações e vitórias em concursos de arquitetura; o Residencial Box House, por exemplo, rendeu ao escritório seu primeiro prêmio: Premiação IAB-SP 2008. O Grupo SP constitui-se na associação de arquitetos formados em diferentes momentos, que se reuniram para o desenvolvimento de concursos e projetos desde $2004 \mathrm{com}$ sede em São Paulo. O UNA Arquitetos é uma associação de profissionais formados pela Faculdade de Arquitetura e Urbanismo da USP e foi fundado em 1996. O escritório trabalha em projetos de diferentes programas e escalas, incluindo projetos urbanos, espaços culturais e edifícios residenciais e comerciais.

Esta investigação utiliza-se da técnica do redesenho dos projetos para produzir percursos no nível do observador, buscando explorar possíveis locais de permanência e passagem geradas pela configuração espacial de cada proposta. Os percursos envolvem as relações privadas dentro das unidades habitacionais, a relação da unidade privada com as áreas condominiais, e a interface entre as áreas condominiais e o espaço público aberto. Dentro desse contexto, propõem-se uma exploração da possível percepção visual do transeunte e da qualidade do espaço a ser gerado, isto é, uma percepção virtual à priori, entendendo que bastante restritiva quando comparada à complexa realidade, mas extremamente didática e pedagógica para o ensino da Arquitetura e do Urbanismo. Acredita-se que ao analisarmos os projetos de arquitetura de habitação social produzidos pelos escritórios listados estaremos também apontando para possíveis padrões de habitabilidade e urbanidade contemporâneos.

As questões que envolvem a produção da Habitação de Interesse Social no Brasil são complexas e envolvem temas polêmicos como a definição de políticas públicas, a segregação espaço-social urbana, o valor do solo, a equidade social, eficiência e sustentabilidade urbana e ambiental. Devido à complexidade do tema, este estudo representa uma amostra da produção da habitação social em um recorte temporal, o período Pós-BNH. Em 1986, com o fim do BNH (Banco Nacional de Habitação) e a promulgação da Constituição de 1988, surge uma nova fase da política habitacional brasileira denominada "Pós-BNH" (MARICATO, 2002). A elaboração desse período foca-se na produção da habitação social com experiências alternativas, como concursos públicos e iniciativas público-privadas; essas, por sua vez, começaram a apresentar sugestões que fogem do tradicionalismo da organização espacial das moradias mínimas.

Nesta investigação realiza-se análises em três escalas do projeto arquitetônico e suas diferentes interações com o entorno: pretende-se fazer um diagnóstico do objeto em si, suas relações com o espaço e com o contexto urbano, embasado pelos conceitos de urbanidade e habitabilidade descritos por Barros e Pina (2011). O estudo se justifica por desenvolver uma análise da produção da habitação social realizada pelos referidos escritórios, e consequentemente, por promover uma crítica à inserção urbana da habitação social na atual realidade brasileira. A investigação estrutura-se sobre questões como: as estratégias projetuais utilizadas na configuração das unidades habitacionais favorecem a habitabilidade arquitetônica e a urbanidade? Qual a estratégia projetual de implantação do conjunto habitacional? Como ocorrem as relações sócio espaciais dentro da área condominial? As habitações refletem características locais de habitabilidade e urbanidade? Como se estabelecem as relações sociais entre público e privado? 


\section{CONTEXTUALIZAÇÃO SÓCIO ESPACIAL DA HABITAÇÃO SOCIAL}

O histórico da habitação social no Brasil remete a meados de 1920, com a produção de programas habitacionais de casa mínima, vilas operárias e moradias higiênicas, orientadas pelos movimentos sanitaristas da época e demonstrando uma preocupação com a moradia para a classe operária. A partir de 1931, com o Primeiro Congresso de Habitação sediado em São Paulo é acrescentado a lógica de interesse pela cidade em conjunto com a relação moradia-trabalho. No entanto, é no início da industrialização no Brasil e com o deslocamento da população do campo para a cidade que a demanda para moradia aumenta, assim, na "Era Vargas" surgem as propostas de habitação social com interferência do Estado em políticas de aluguéis, produção e financiamento de moradia. Mas é apenas em 1940, com a construção dos primeiros prédios modernistas, que a ideia da casa própria ganha uma centralidade mantida até os dias de hoje. Em 1950, iniciou-se a construção de grandes edifícios habitacionais próximos à infraestrutura urbana e na década seguinte foi criado o Banco Nacional de Habitação, em um contexto político e econômico de regime militar instalado com o golpe de 1964. O BNH financiou moradias em todo o país no período de 1964 à 1986, atuando nos estados e municípios via Companhias de Habitação Popular, Cohabs (Companhias de Habitação Popular) e Departamentos Municipais de Habitação com a finalidade de diminuir o déficit habitacional, substituir as moradias nas áreas das favelas, promover a venda de lotes urbanizados e financiar o saneamento ambiental. O BNH extingue-se em 1986, então até 2009, o país fica sem um programa habitacional nacional integrado: esse período denomina-se Pós-BNH. Nessa fase ocorreu a descentralização da gestão e produção da habitação social, dividindo a responsabilidade da moradia às três instancias governamentais, municipal, estadual e federal (BONDUKI, 2014). O fator local passou a ser mais valorizado, as ações mais pontuais, com mais propostas em pequena escala e com base na regularização fundiária. Se por um lado, as propostas descentralizadas trouxeram alguns fatores adversos, tais como as dificuldades de gestão financeira e institucional, por outro lado, ocorreram algumas experiências inovadoras de promoção habitacional e de democratização da cidade, que tentam reverter a tendência de promoção de grandes loteamentos e conjuntos habitacionais na periferia. A partir de 2009 surge o PMCMV que objetiva ser uma política anticíclica contra os efeitos nocivos da crise mundial (D'AMICO, 2011). Além de atender o déficit habitacional, o PMCMV visa aumentar investimentos no setor para garantir emprego e renda, principalmente na construção civil, na tentativa de diminuir os impactos da crise econômica internacional dentro do país. Identifica-se como padrão nas políticas habitacionais brasileiras, o incremento da economia através do incentivo à construção civil, tanto na construção das moradias como na implantação de infraestrutura para atender as localizações periféricas dos conjuntos habitacionais. Dentro deste cenário, observa-se que o padrão das políticas públicas de habitação no Brasil busca atender o déficit habitacional incorporando o incremento do crescimento econômica através da geração de empregos na construção civil, mas de outro lado, oneram o poder público com custos de infraestrutura para atender a localização periférica dos conjuntos habitacionais.

A amostra de Conjuntos de Habitação Social estudados insere-se no período histórico designado como Pós-BNH, são eles: Residencial Ipê Amarelo (2003) - Arquitetos Associados, Residencial Box House (2008) - Escritório Yuri Vital, Concurso Habita Sampa Assembleia (2004) - propostas do Grupo SP e UNA Arquitetos. Historicamente, o estado de Minas Gerais tem uma relação de planejamento quanto às suas cidades. Belo Horizonte, por exemplo, quando se tornou capital mineira, em 1930, teve um planejamento para readequação urbana aos ideais da época. O plano para Belo Horizonte reflete muito as concepções urbanísticas com o traçado de diagonais sobreposto ao traçado ortogonal, as áreas verdes como espaços importantes da cidade e grandes quarteirões. Pode-se observar reflexos desse planejamento da capital na cidade de Sete Lagoas, onde se insere o Residencial Ipê Amarelo do Arquitetos Associados. A iniciativa desse escritório consiste na construção de habitações de baixo custo, explorando a localização em áreas limítrofes. O residencial Ipê Amarelo tem implantação de tipologia horizontal, situado em uma área que demarca a dispersão do centro de Sete Lagoas e a proximidade da área rural, mais precisamente na esquina da Av. das Nações com a R. Prof. Alberto Paes.

A cidade de São Paulo iniciou seu crescimento urbano por volta de 1880, com a formação dos bairros predominantemente residenciais nas áreas mais altas do município, e bairros operários, nos terrenos de baixada. Em meados de 1900 a necessidade de melhorias nas moradias dos operários exigiu alterações com ideais de higiene e economia. O centro da cidade começou a se degradar a partir dos anos 1940 fazendo com que somente a partir de 2001, a prefeitura de São Paulo voltasse suas atenções ao centro e à questão da moradia popular, criando programas para reabilitação da área e concursos de Habitação de Interesse Social. Essas iniciativas foram impulsionadas pelo programa "Morar no Centro", que objetivava a ocupação de edificações e terrenos desocupados na região. O Concurso HabitaSampa e o Residencial Box House foram concebidos dentro dessas iniciativas que incluíam a revitalização do centro paulista a partir de 
parcerias público-privadas (PPPs), e operações consorciadas e projetos de arquitetura realizados através de concursos públicos de arquitetura e urbanismo. Um dos concursos promovidos pela prefeitura de São Paulo, na gestão de 2001 à 2004, é o Habita Sampa - Conjunto Cônego Marino, - que tinha como objetivo a implementação de um conjunto habitacional em terreno público desocupado no bairro Barra Funda. $\mathrm{O}$ terreno fica em uma esquina e é delimitado por uma linha férrea e por um parque estadual. $O$ edital do concurso estipulou que deveriam ser inseridas, no conjunto das unidades habitacionais, células de 1 dormitório, de dois dormitórios e também quitinetes. Foi estabelecido um gabarito máximo de quatro pavimentos - que busca coerência com as características do entorno. Além das habitações, também deveria ser projetado no terreno um Centro de Capacitação em Restauração e Reformas (CCRR), que se comportaria como um centro de ensino para formar mão de obra especializada para a execução das reformas e restaurações na área central. Também era solicitado um espaço que poderia servir como depósito do Departamento de Patrimônio da Prefeitura.

O conjunto residencial Box House, desenvolvido pelo escritório Yuri Vital, é situado no perímetro urbano de São Paulo, na Zona Norte, na Av. Itaberaba, bairro Brasilândia. O bairro foi formado por pequenas chácaras e, aos poucos, foi loteado e edificado, conferindo à paisagem local uma falta de planejamento nas residências. Nesse contexto, o projeto Box House pretendia trazer um diferencial à paisagem local, sendo implantado em tipologia formal de "caixas" modulares, objetivando reduzir custos. Além disso, pode-se observar o objetivo de aliar qualidade estética e funcional com a praticidade de construção e baixo custo.

O Quadro 1 sintetiza algumas informações complementares a respeito dos empreendimentos analisados neste estudo, como: ano de ocupação, número de unidades habitacionais, tipologia da habitação, arranjo da implantação, tipo de empreendimento e área total.

Quadro 1: Principais características dos empreendimentos analisados no estudo.

\begin{tabular}{|c|c|c|c|c|c|c|}
\hline $\begin{array}{l}\text { Nome do } \\
\text { Emprend. }\end{array}$ & $\begin{array}{c}\text { Ano de } \\
\text { Ocupação }\end{array}$ & U.H. ${ }^{1}$ & Tipologia Arquitetônica & $\begin{array}{l}\text { Arranjo de } \\
\text { Implantação }\end{array}$ & $\begin{array}{c}\text { Modelo de } \\
\text { Empreendimento }\end{array}$ & Área \\
\hline Ipê Amarelo & 2003 & $\begin{array}{l}2 \text { hab./unid } \\
8 \text { unidades }\end{array}$ & Sobrados de 2 pav. & $\begin{array}{c}\text { Fita - contínua Nordeste/ } \\
\text { Sudoeste }\end{array}$ & Condomínio fechado & $450 m^{2}$ \\
\hline Box House & 2008 & $\begin{array}{l}4 \text { hab./unid } \\
15 \text { unidades }\end{array}$ & Sobrados de 2 pav. & $\begin{array}{c}\text { Fita } 1 \text { - contínua } \\
\text { Fita } 2 \text { - escalonadas N/S }\end{array}$ & Condomínio fechado & $1011 m^{2}$ \\
\hline $\begin{array}{l}\text { Habita } \\
\text { Sampa } \\
\text { UNA }\end{array}$ & - & $\begin{array}{l}\text { 2hab/uni(kitnet) } \\
\text { 2hab/un (1 dor) } \\
\text { 4hab/uni (2 dors) } \\
240 \text { unidades }\end{array}$ & $\begin{array}{l}\text { Unidades habitacionais: } \\
\text { quitinete, } 2 \text { dormitórios e } 1 \\
\text { dormitório }\end{array}$ & $\begin{array}{c}\text { blocos híbridos paralelos } \\
\text { Leste/Oeste }\end{array}$ & $\begin{array}{l}\text { Conjunto Habitacional - } \\
\text { programa de locação } \\
\text { social }\end{array}$ & $11.955,8 \mathrm{~m}^{2}$ \\
\hline $\begin{array}{c}\text { Habita } \\
\text { Sampa } \\
\text { Grupo SP }\end{array}$ & - & $\begin{array}{l}\text { 2hab/uni(kitnet) } \\
\text { 2hab/un (1 dor) } \\
\text { 4hab/uni (2 dor) } \\
240 \text { unidades }\end{array}$ & $\begin{array}{l}\text { Unidades habitacionais: } \\
\text { quitinete, } 2 \text { dormitórios e } 1 \\
\text { dormitório }\end{array}$ & $\begin{array}{c}\text { blocos contínuos } \\
\text { Leste/Oeste/Norte/Sul }\end{array}$ & $\begin{array}{l}\text { Conjunto Habitacional - } \\
\text { programa de locação } \\
\text { social }\end{array}$ & $10.692 m^{2}$ \\
\hline
\end{tabular}

Fonte: Produzido pelas autoras.

\section{METODOLOGIA DA PESQUISA}

A avaliação pós-ocupação (APO) é um dos métodos de retroalimentação do processo de projeto, permitindo a identificação de estratégias projetuais bem-sucedidas e aquelas que devem ser revistas. Neste método a percepção do usuário é representada pelos índices de satisfação, e a avaliação técnica construtiva pode ser verificada através do uso do empreendimento e do tempo. No entanto, esta pesquisa centra-se na investigação do processo projetual através da exploração dos espaços gerados em percursos virtuais no 3D. A definição dos percursos segue critérios utilizados nas análises físico visuais (CULLEN,2006; PANERAI,2009) incluindo como categorias de análise os conceitos de Urbanidade e a Habitabilidade (BARROS e PINA, 2011).

A metodologia da pesquisa envolve uma etapa inicial de levantamento documental nas websites dos escritórios, complementadas com informações coletadas em produções técnico-científicas. A partir da documentação gráfica obtida são realizados os redesenhos dos projetos selecionados, de acordo com padrões previamente estabelecidos no Grupo de Pesquisa. A prática do redesenho é importante, pois estabelece uma relação dialética entre o pensamento indutivo e dedutivo. Esta prática potencializa as 
interpretações e explorações das práticas e dos padrões e/ou inovações projetuais através das representações dinâmicas produzidas pelas técnicas de visualização 3D (RAMOS, 2016).

Após a etapa do redesenho, definem-se as categorias de análise relacionadas ao senso de habitabilidade, referente à escala da edificação e das unidades habitacionais; e o senso de urbanidade, que se refere à escala da implantação e da sua interação com o espaço público, tentando apontar os benefícios que determinadas tipologias podem gerar na dinâmica socioeconômica do seu entorno urbano. A classificação e análise dos conjuntos habitacionais seguem os estudos tipológicos da habitação econômica (BONDUKI, 2003), possibilitando a geração de dados quantitativos e comparações objetivas entre os conjuntos habitacionais.

O termo urbanidade pode ser extremamente amplo e de difícil definição, envolvendo critérios como a qualidade do ambiente construído pelo homem (CASTELLO, 2017), caráter urbano e conjunto de qualidades, boas ou más, que constituem a cidade (AGUIAR, 2012) dentre tantas outras conceituações. Neste estudo, utiliza-se os conceitos humanizadores contemporâneos descritos como senso de urbanidade e senso de habitabilidade (BARROS e PINA, 2011).

Dessa forma, investiga-se as possibilidades de interação entre Arquitetura e Cidade geradas por esses projetos, inferindo a respeito de padrões de urbanidade e também habitabilidade, além de possíveis inovações na sociabilização dos espaços públicos contemporâneos. A análise sistêmica da interação arquitetônica e urbana pode ser identificada em Jacobs (2000) e Gehl (2013). Há mais de 40 anos Jane Jacobs já indicava as condições básicas para uma cidade viva: uma urbe vicejante, constituída pela alta densidade e diversidade socioeconômica, cultural, de estoques construídos e usos. Em "Morte e Vida de grandes cidades", Jacobs (2000) aponta para componentes da forma arquitetônica que favorecem a maior vivacidade urbana, como janelas e portas voltadas para rua, elementos que surgem bem mais detalhados por Gehl (2013). Na publicação "Cidades para Pessoas", Jan Gehl concentra-se na permeabilidade física e visual entre a edificação e o espaço público, pontuando a importância de espaços de transições suaves entre o público e o privado como elemento chave para uma cidade viva, segura, sustentável e saudável.

\section{INVESTIGAÇÃO DOS CONCEITOS DE URBANIDADE E HABITABILIDADE}

A investigação dos conceitos humanizadores são baseados no senso de urbanidade e habitabilidade (BARROS e PINA, 2011), pontualmente analisados em cada Conjunto de Habitação de Interesse Social. As análises são realizadas separadamente para cada senso, e apresentadas concomitantemente entre os residenciais horizontais em comparação com os conjuntos habitacionais verticais. No senso de urbanidade primeiro a ser analisado - são sintetizadas as necessidades dos usuários, requisitos técnicos e geográficos relativos ao entorno de cada conjunto, e consequentemente as interações da implantação na configuração de espaços externos positivos. Tais aspectos são representados por três categorias, das quais as duas a seguir serão utilizadas neste estudo: (i) conectividade, legibilidade e sustentabilidade social; (ii) identidade.

O senso de habitabilidade, por sua vez, se embasa na relação entre a implantação e a unidade habitacional, focando na apropriação para realizar atividades domésticas; um sentido de habitar que atenda às necessidades de refúgio, isolamento, convivência, ordem e variedade (BARROS e PINA, 2011). Diz respeito à relação da estrutura física da unidade habitacional com os espaços de convívio gerados em torno dela, dando prioridade à existência de um gradiente de privacidade. Também trata de condições de habitabilidade, tais quais conforto térmico, proporção entre iluminação natural e artificial, elementos estéticos como acabamentos e materialidade; também leva em consideração a adaptabilidade dos espaços de acordo com a diversidade de usuários que as células habitacionais têm potencial para abrigar. Todos esses aspectos de habitabilidade, são divididos em três categorias de análise, conforme segue: (i) harmonia espacial, conforto ambiental e privacidade; (ii) sentido de lar; (iii) opções e flexibilidade.

\section{Urbanidade}

A partir de uma análise físico visual do projeto do Arquitetos Associados é possível depreender a estratégia de maior privacidade em relação ao entorno, e o perímetro murado, e elevação de empenas cegas contornando demostra certa reprodução de um costume local, quando da análise das implantações adjacentes. Assim, nota-se pouca sensibilidade ao ambiente construído e natural, à medida que estabelece um impacto ambiental e não explora a relação com a vasta área verde à frente do terreno. $\mathrm{O}$ conjunto tampouco segue o gabarito e continuidade rigorosa da malha urbana, pois as empenas das extremidades são ligeiramente mais altas que o todo murado. Além disso, não há interfaces permeáveis entre a rua e o entorno, pois o caminho criado entre espaço público e condominial gera uma rígida transição de privacidade, reforçado pela hierarquia de acesso criada pelo pórtico de entrada. 
Por sua vez, o Box House, também se preocupa com a delimitação do perímetro do terreno, contudo através de um gradil nos fundos e um grande muro na entrada principal, buscando outras estratégias para prover a privacidade visual de todo o conjunto. A relação dessas soluções apresentadas por ambos escritórios mostra uma preocupação similar com a interação entre público privado, através do fechamento ao invés de relações de livre acesso e passagem de pedestres, conforme Figura 1. Quanto ao impacto visual inicial, é baixo, pelo conjunto estar inserido na malha urbana e configurar tecido. Ainda assim, não apresenta interfaces permeáveis com a rua de entrada, apenas com a paisagem ao fundo do terreno do condomínio. Não há transição gradual entre as esferas pública e privada, enfatizada especialmente pela ausência de permeabilidade física e visual.

Figura 1: Condicionantes Urbanos.

1(a) Residencial Ipê Amarelo - Arquitetos Associados

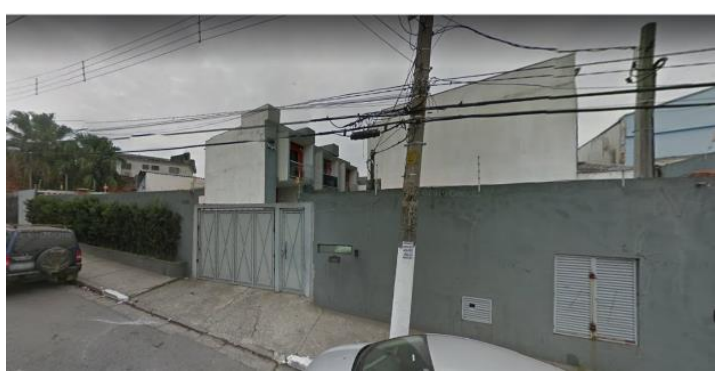

1(b) Residencial Box House - Yuri Vital

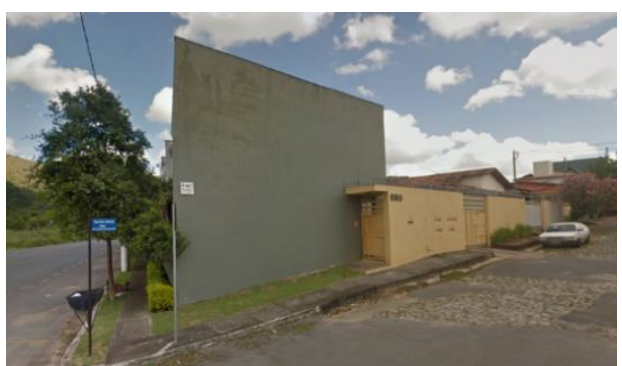

Fonte: Street view (Google).

Para conferir maior qualidade espacial ao projeto e humanizar a arquitetura, entende-se a necessidade de buscar implantações e conjuntos formais que priorizem a escala humana, com edificações de porte reduzido, além de uma valorização dos espaços verdes. Ademais, sabe-se que as grandes cidades brasileiras revelam maior fragmentação espacial e baixo grau de permeabilidade, ou seja, de acessibilidade tipológica na variedade de espaços externos que integram o contexto urbano (BARROS, PINA, 2011). A partir disso, percebe-se que a implantação de ambos os escritórios - tanto Arquitetos Associados, quanto Yuri Vital - adequa-se no que diz respeito a respeitar a escala humana e reduzida, contribuindo para a continuidade do tecido urbano em que estão inseridos, de baixo gabarito, e unidade formal entre as fachadas adjacentes.

No que diz respeito à conectividade e legibilidade entre o condomínio Residencial Ipê Amarelo e seu desenho urbano, não há recuo em relação à calçada, ou espaços coletivos abertos entre o conjunto e a rua. A estrutura formal das unidades aliada à fronteira criada pelo perímetro murado, nega a permeabilidade e possibilidade de maior conexão dentro-fora. No quesito vivacidade urbana oferecida pelo conjunto, não há ocorrência de sustentabilidade social, pela baixa diversidade de usos na vizinhança, como ilustra Figura 2a. Ademais, o que mais diverge do entorno densificado é a grande área verde (fazenda e propriedade privada) à frente da Av. das Nações, única orientação de fachada permeável do condomínio. Todavia, as tipologias e programas de moradias do entorno, conforme dito anteriormente, parecem seguir uma tradição do habitar local, criando identidade visual com o contexto urbano.

No caso do Box House - Yuri Vital, a conectividade do conjunto com seu contexto é comprometida pela baixa identidade visual. $\mathrm{O}$ projeto possui uma rua interna condominial que distribui a circulação para as unidades habitacionais; essa, por sua vez, proporciona um eixo de visibilidade para os fundos do lote, especialmente por ser delimitado por um gradil. A partir dessa vista, pode-se observar alta densificação de moradias sobre uma topografia elevada, com conjuntos habitacionais espontâneos de pouca unidade formal, mas gabarito semelhante. Seu entorno urbano possui pouca diversidade de usos (Figura 2b), que majoritariamente são estabelecimentos comerciais alimentícios, com apenas uma instituição de ensino, algumas instituições religiosas e uma grande praça, estabelecida como a única área verde em um raio considerável de densidade urbana. Dessa forma, a sustentabilidade social, descrita por Barros e Pina (2011), é comprometida pela baixa conexão dentro-fora e falta de espaço coletivo aberto integrando o conjunto ao entorno. 
Figura 2: Inserção urbana dos conjunto habitacionais.

Comércio Parque Escolas Instituições religiosas
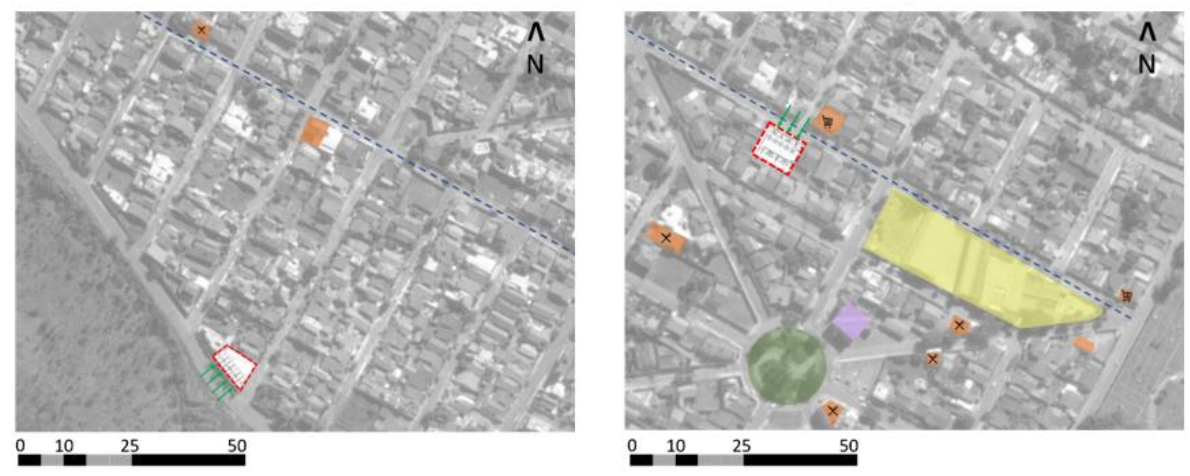

Fonte: Produzido pelas autoras sobre imagem do GoogleMaps.

A identidade das pessoas com o lugar, principalmente em se tratando de unidades habitacionais, está relacionada a espaços externos positivos que sejam convidativos e estimulem a permanência dos moradores, que estejam nas áreas condominiais ou pátios internos, por exemplo. Conforme Barros e Pina (2011), a existência de um espaço coletivo aberto pode contribuir para a criação de um sentido de lugar, e esses espaços podem ser potenciais conexões com a cidade, sem abrir mão de uma maior privacidade.

Nesse contexto, os projetos de tipologias horizontais analisados falham na criação de espaços abertos de convivência, tornando a área condominial um espaço destinado apenas à circulação, não convidativa a atividades de permanência. No caso do Residencial Ipê Amarelo a vegetação existente não se articula para conformar e distinguir espaços, se não para gerar apenas uma área de sombreamento nos pátios interno das unidades e criar uma espécie de eixo marcando a calçada. Portanto, pode-se dizer que não é explorada uma forma de integração com vegetação, nem são criados estares comuns, como espaços de lazer para crianças, áreas de bancos, áreas cobertas. O percentual de ocupação com área construída, somado à estratégia de implantar os estacionamentos no térreo e os recuos criados em relação aos limites dos terrenos de ambos projetos são fatores determinantes no possível sentido negativo de lugar que os moradores possam criar sobre esse espaço.

$\mathrm{Na}$ análise dos projetos para o concurso HabitaSampa produzidos pelos escritórios GrupoSP e UNA Arquitetos é possível perceber que não há relação tipológica com as edificações do entorno, visto que se caracterizam como grandes conjuntos habitacionais implantados de forma a configurar uma nova quadra, enquanto o entorno é formado majoritariamente por edificações de pequeno porte. Diferentemente dos dois projetos horizontais, as propostas para o concurso HabitaSampa buscam uma maior interação dos espaços condominiais com o espaço público e não criam barreiras físicas - muros - nos limites do terreno. O entrelaçamento entre a edificação e o lugar toma linhas mais ambíguas e acontece de maneiras distintas nos dois projetos. O projeto do UNA, apesar de ocupar grande parte do térreo, cria interfaces permeáveis com o espaço público ao gerar espaços de atividades diversas e acessos para as áreas abertas e blocos do condomínio. Percebe-se uma busca de privacidade das áreas condominiais através da elevação das áreas abertas em um platô, tornando possível a visibilidade somente de dentro para. O projeto do Grupo SP, em contrapartida, parte de edificações elevadas em pilotis, utilizando o térreo como garagens e espaço livre. As áreas abertas condominiais acontecem tanto no nível da rua como em uma praça rebaixada no centro do conjunto e se relacionam visualmente com o espaço público de maneira mais ampla. A ambiguidade está na permeabilidade física e visual das duas propostas, pois enquanto o UNA restringe a visibilidade do público para o privado através da elevação do conjunto, o Grupo SP restringe fisicamente um acesso fluido através do rebaixamento do térreo. Consequentemente, as propostas para o HabitaSampa analisadas, apesar de não estabelecerem relação tipológica com o entorno ou se inserirem no tecido urbano, apresentam algum grau de sensibilidade ao ambiente construído e natural na medida que criam ambientes de transição entre 0 público e o privado e dão continuidade às linhas das vias do entorno dentro do terreno do conjunto.

Quanto à conectividade e legibilidade dos projetos do concurso HabitaSampa em relação ao contexto urbano, pode-se inferir que, apesar de não se integrarem ao tecido, ambos os projetos proporcionam fronteiras permeáveis, com grande variedade de acessos e espaços coletivos abertos que se relacionam com a rua em diferentes graus. No projeto do UNA as duas vias dentro do conjunto, a praça à frente da creche, os acessos do centro de capacitação e o espaço aberto acima do platô se classificam como espaços externos positivos que contribuem para criação de percursos diferenciados e espaços de permanência e contemplação. Da mesma forma, o projeto do Grupo SP também possui uma variedade de espaços externos coletivos e acessíveis, áreas sob pilotis e praça rebaixada que diversificam o percurso e 
configuram locais de permanência. A transição dentro-fora, diferentemente dos projetos dos escritórios Arquitetos Associados e Yuri-Vital não acontece de forma direta e sim através de percursos por espaços semiprivados e/ou semipúblicos, gerando um gradiente de privacidade dentro do conjunto. A vivacidade urbana pode ser incentivada nesses projetos através da diversidade de usuários e de faixas de renda, visto que eles apresentam variedade de unidades habitacionais, podendo então servir para diferentes perfis de usuários. Todavia, a sustentabilidade social também é incentivada pela diversidade de usos do entorno, que possui diversos estabelecimentos comerciais e alimentícios locais, instituições educacionais de pequeno e grande porte, instituições religiosas e uma grande área verde adjacente ao conjunto habitacional, conforme Figura 3.

Em grande contraste aos projetos previamente analisados no quesito identidade, as propostas do UNA e do Grupo SP para o HabitaSampa apresentam como potencial a criação de espaços abertos de convivência, que não se limitam somente à circulação dentro do conjunto habitacional, mas que criam espaços de permanência, com a presença de vegetação e áreas verdes. No projeto do UNA, as áreas abertas acontecem entre os blocos habitacionais sobre o platô e recebem área com vegetação que contribui para distinguir usos de permanência com sombra e somente circulação. Da mesma forma, o Grupo SP cria uma praça rebaixada no centro do conjunto habitacional que se caracteriza como espaço de permanência e que é circundada por espaços verdes com vegetação alta que cria estares de sombra. Outro parâmetro para a criação de identidade, segundo BARROS E PINA (2011), é o encorajamento de uma diversidade de usuários, que já foi relacionada neste artigo à variedade de unidades habitacionais destes projetos. Pode-se concluir, portanto, que as propostas do UNA e do Grupo SP se qualificam mais positivas quanto ao sentido de lugar e identidade visto que potencializam os espaços abertos, criam um gradiente de privacidade no arranjo do conjunto e influenciam uma diversidade de usuários.

Figura 3: Inserção urbana dos conjuntos habitacionais.

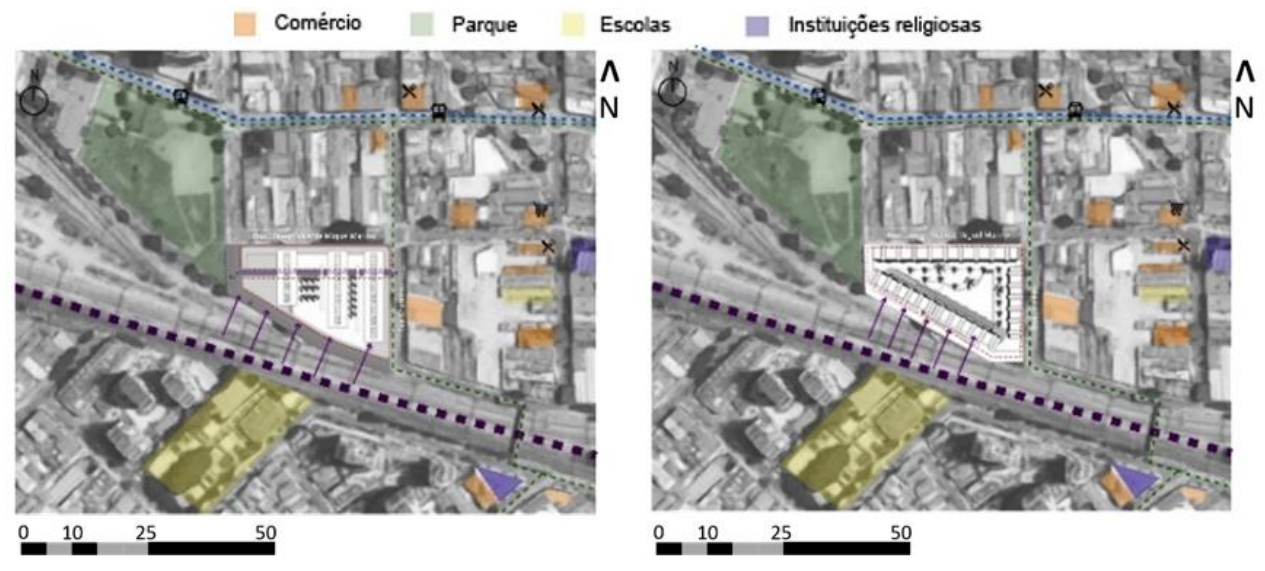

Fonte: Esquema Gráfico - Diagramas produzidos pelas autoras sobre imagem GoogleMaps.

\section{Habitabilidade}

A distribuição de luz nas unidades do Residencial Ipê Amarelo segue orientação nordeste/ sudoeste (conforme Figura 4a) A distribuição da fita proporciona a existência de apenas um eixo que distribui as unidades em uma extremidade do perímetro (Figura 4b), definindo uma rua interna do condomínio e uma circulação do tipo pente. As entradas principais das células são voltadas para a área condominial e esse eixo de circulação distributivo. A iluminação natural nas unidades se distribui de forma eficiente devido à organização estreita da planta, que torna a luz mais canalizada e menos difusa ao longo dos estares. Neste caso, há ventilação cruzada proporcionada por janelas opostas que dão para o pátio interno e para a área condominial. Em contrapartida, essa estratégia confere menor privacidade, por não haver permeabilidade em relação à área condominial. Dessa forma, o gradiente de privacidade no arranjo do conjunto oferece controle visual da unidade para a rua: possibilitado por janelas contínuas na lateral e na parte superior da fachada, iluminando de forma prioritária as áreas molhadas; e controle da unidade para a área comuns: possibilitado pela porta envidraçada de acesso principal e janela do dormitório. As oito unidades têm permeabilidade visual e física igualitária, todas com aberturas equivalentes tanto para a rua pública quanto para a rua interna.

A orientação solar proporcionada pela implantação do Box House se dá de forma que o arranjo das fitas contínuas que unem as células garante uma iluminação norte/sul para suas aberturas, como apresentado na Figura 4c. O aproveitamento de luz natural privilegia de formas diferentes cada fita, devido à organização das unidades que se baseia em um eixo de distribuição em que há espelhamento e circulação tipo espinha de peixe (Figura 4d); sete unidades têm orientação norte (mais vantajosa) para o dormitório principal e as 
áreas de estar social, enquanto oito unidades recebem iluminação norte voltada para o segundo dormitório e as áreas molhadas. Ainda assim, o estreitamento da planta das unidades facilita uma maior distribuição de luz e gradação de privacidade interna. Por sua vez, a ventilação cruzada ocorre entre aberturas opostas apenas, pois as paredes laterais estão comprometidas - os sobrados são adjacentes uns aos outros.

No projeto Ipê-Amarelo, observa-se a estratégia projetual de repetição e espelhamento de plantas adjacentes, formando um padrão dentre as unidades; tanto a planta baixa térrea, como a planta do segundo pavimento da unidade habitacional se desenvolve de forma a criar espaços sequenciais com uma configuração linear de circulação. Na planta térrea verifica-se uma única possibilidade de acesso ao pátio através da cozinha, enquanto que na planta superior observa-se que o dormitório está voltado para o interior do condomínio e não para o pátio privado. Infere-se que neste residencial o "habitar" representa as necessidades de um único morador ou casal jovem com permanência noturna na habitação. Há um público específico que tem potencial para desenvolver um sentido de lar à unidade, com pouca variedade de possíveis usuários. Esta observação é reforçada pela localização do banheiro no mesmo pavimento do dormitório, a área social com apenas uma abertura para a área condominial, e sem conexão visual nem física com o pátio privado da habitação.

Ambos os projetos de tipologia horizontal possuem plantas com coordenação modular nas grelhas estruturais, a partir de módulos irregulares; a organização de ambientes de estar e dormitórios permite que sejam mais amplos que os demais, possibilitando a circulação e a disposição dos móveis nos ambientes. A organização hidráulica dos ambientes se dá através de módulos simples, à exceção da Box House, que possui dois módulos distintos. No residencial Box House a unidade habitacional constitui-se a partir de dois módulos para dormitórios, um módulo dividido entre estar e cozinha e um módulo adicional para área externa no pavimento térreo. O estar e a cozinhar são integrados e permitem a flexibilidade na configuração básica do mobiliário, sendo cada unidade projetada para abrigar uma família, em média, quatro moradores (Figura 5).

Figura 4: Condicionantes Ambientais e Tipologia Habitacional.
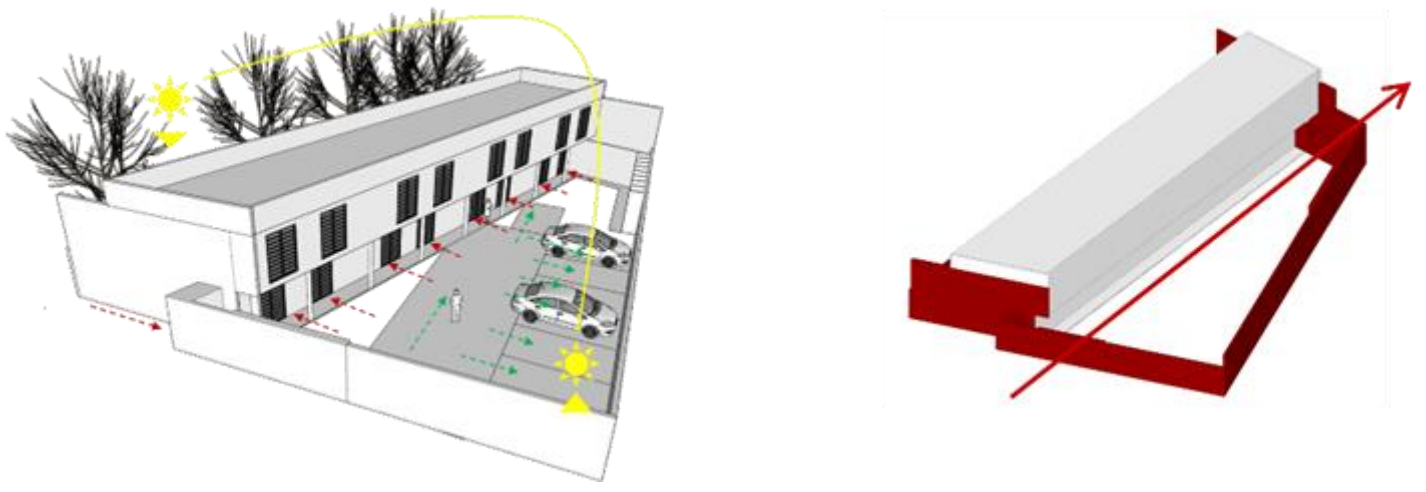

4(c) Box House - orientação solar e fluxos (verde: carros; vermelho: pedestres) 4(d) Partido Formal

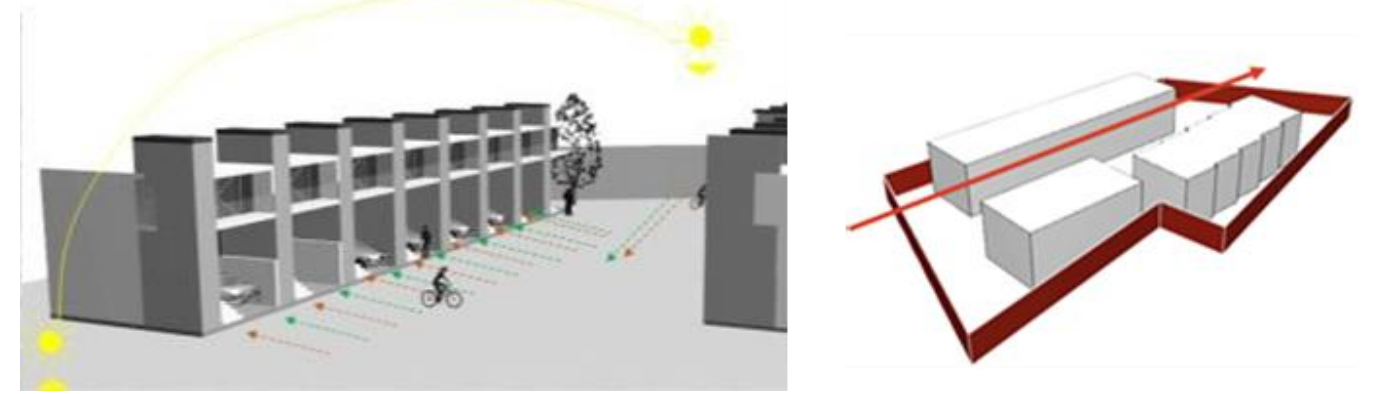

Fonte: Esquema Gráfico - Redesenhos, Diagramas e Imagens 3D produzidos pelos autores. 
Figura 5: Arranjo espacial das unidades habitacionais - $1^{\circ}$ e $2^{2}$ pav. Ipê Amarelo/ Box House (da esquerda para a direita).

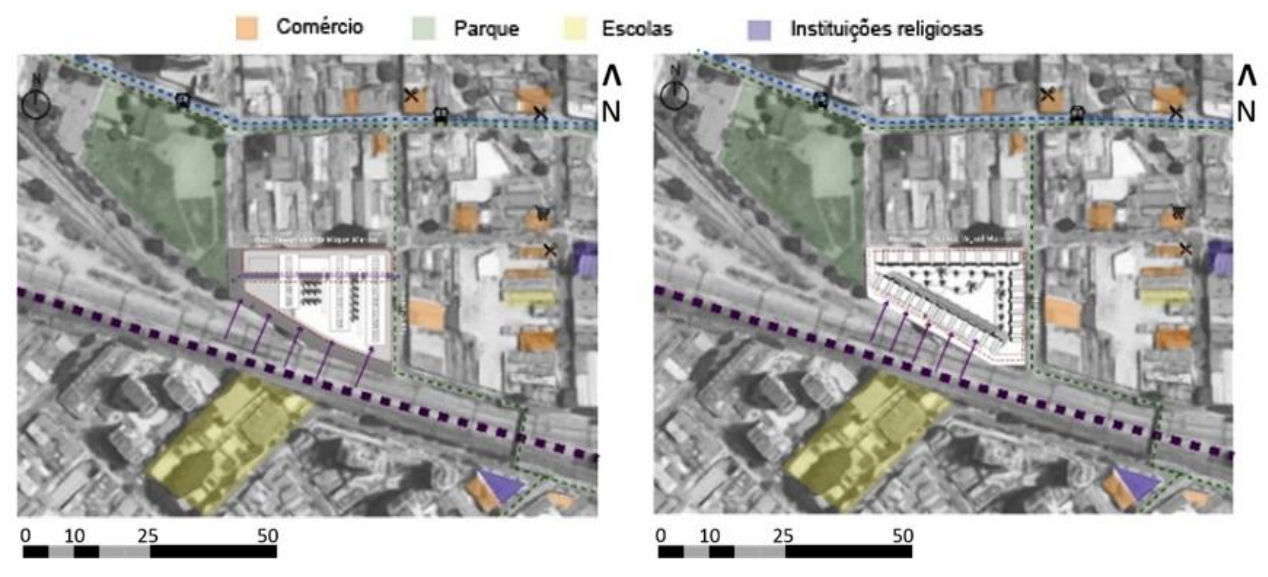

Fonte: Esquema Gráfico: Redesenhos, Diagramas produzidos pelos autores.

Nas unidades básicas desse projeto observa-se a compartimentação das área de estar, sendo as paredes o elemento de definição espacial. Verifica-se a criação de áreas externas privadas nos fundos das unidades. Esses espaços possibilitam alguma ampliação, desde que os limites mínimos para as aberturas, ventilação e iluminação sejam respeitados. Essas ampliações podem ocorrer tanto no pavimento térreo como no segundo pavimento (Figura 6a). Todavia, as células habitacionais apresentam apenas uma unidade de área íntima. Essa falta de flexibilidade apresenta pontos negativos por não haver adaptabilidade em relação ao crescimento da família que pode vir a habitar o Residencial Ipê-Amarelo. Por outro lado, a unidade proposta por Yuri Vital apresenta maior flexibilidade (Figura 6b), com uma área de entrada no primeiro pavimento seguida de um amplo espaço de estar, onde o mobiliário se configura como elemento de definição espacial. As opções de ampliação do Box House, portanto, concentram-se basicamente no fechamento da garagem e da sacada do dormitório, conforme Figura $6 b$.

Figura 6: Quadro comparativo entre unidades habitacionais - Possibilidade de flexibilização (em azul).
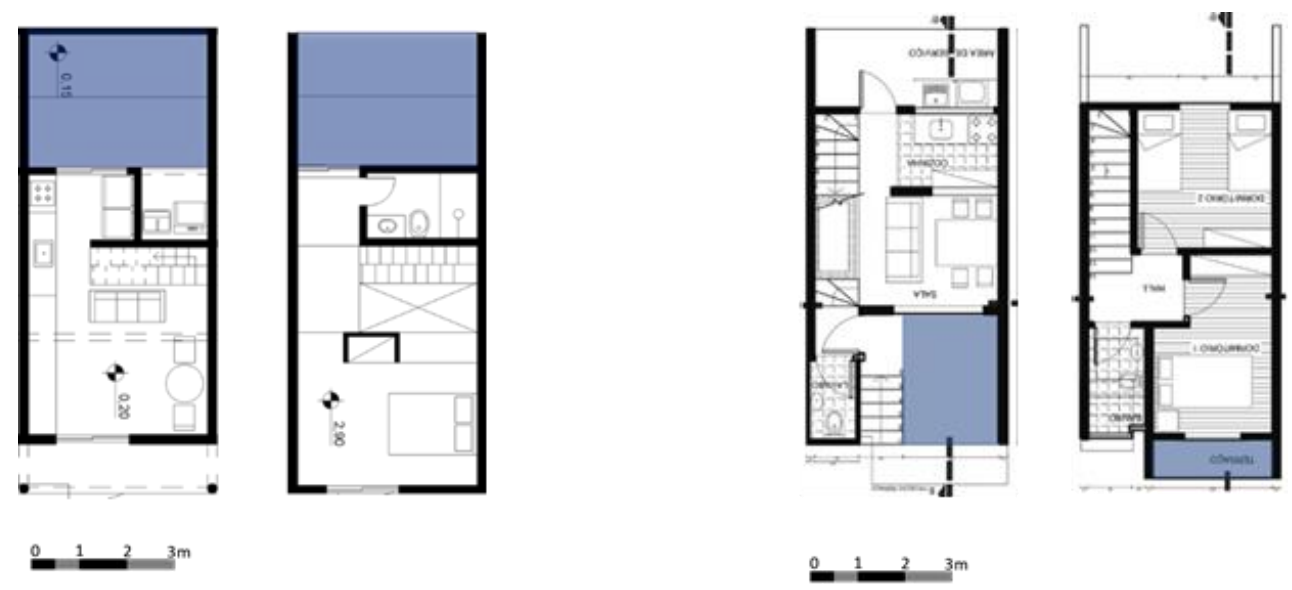

Fonte: Esquema Gráfico - Redesenhos e Diagramas produzidos pelos autores.

Os projetos do Grupo SP e do UNA Arquitetos para o HabitaSampa se caracterizam como grandes conjuntos habitacionais e, em decorrência, a avaliação da habitabilidade se torna mais complexa na medida que as unidades habitacionais não se relacionam diretamente com o espaço condominial aberto e sim se organizam em pavimentos tipo. Essa organização cria um conjunto de circulações verticais e horizontais que configuram espaços condominiais semi privados dentro do bloco habitacional que, por sua vez, mantém relação com as áreas abertas. Dessa forma, é necessária também uma avaliação do posicionamento das unidades habitacionais no pavimento tipo para a definição de parâmetros como a orientação, distribuição de luz e estratégias para privacidade.

O projeto do UNA propõe uma implantação dos blocos habitacionais de forma paralela, que possibilita que todas as unidades possuam orientação solar leste ou oeste (Figura 7a). Isto se dá visto que o pavimento tipo do projeto se configura como dupla fita, como mostra a Figura 7b, com circulação horizontal central, fazendo com que as unidades se abram tanto para a rua e espaços condominiais abertos - orientadas para leste ou para oeste - quanto para a circulação horizontal condominial. A distribuição de luz na unidade habitacional acontece mais nas aberturas para suas faces externas, que são mais amplas e iluminam os 
dormitórios e o estar social. Na outra face das unidades ficam janelas altas em fita que se abrem para a circulação do pavimento e que recebem pouca luz através de zenital acima da circulação do bloco. Todavia, quanto à privacidade dos usuários, as janelas altas garantem que não haverá visibilidade entre as unidades e o corredor condominial.

No projeto do Grupo SP, a implantação dos blocos habitacionais é feita de forma periférica no terreno e não demonstra preocupação com a orientação das unidades habitacionais (Figura 7d). $O$ pavimento tipo se configura como fita simples - Figura $7 e$ - com circulação vertical múltipla, permitindo que as unidades se abram tanto para a rua quanto para as áreas internas do condomínio. Na unidade do Grupo SP, o estar social e os dormitórios possuem aberturas adequadas às suas dimensões e os módulos hidráulicos possuem aberturas reduzidas, mas que se abrem diretamente para o exterior. Consequentemente, a luz natural será melhor distribuída entre os ambientes do que no projeto do UNA - todavia sem uma preocupação quanto à orientação solar, visto que haverá unidades com orientação norte/sul.

Nos projetos para o concurso HabitaSampa, a diferenciação entre o percurso externo e interno ocorre no âmbito condominial e acontece através da circulação dentro dos blocos habitacionais nos pavimentos. Todavia, não há elementos que marquem a transição de privacidade entre o corredor e as unidades (transição entre espaço semiprivado e espaço privado). Os espaços de circulação e a diferenciação do percurso dentro dos blocos apresentam grandes diferenças entre as duas propostas (Figura 8). O UNA estabelece uma grande circulação horizontal que atende a um grande número de unidades habitacionais e se caracteriza como um espaço provedor de convivência entre os moradores. Nesta proposta, há uma circulação vertical principal que atende a todos os pavimentos e escadas secundárias que diminuem o percurso para os moradores das unidades mais afastadas, conforme Figura 8a. O Grupo SP estabelece espaços de circulação horizontal mínimos, que atendem apenas a duas unidades habitacionais por pavimento e circulação vertical múltipla - não criando espaços de convivência dentro dos blocos (Figura 8b).

Ainda que as unidades habitacionais do UNA e do Grupo SP distribuam os ambientes de maneiras distintas, é possível notar em ambos uma compactação dos ambientes. Em ambas as propostas não há possibilidade de flexibilização dos ambientes que não seja por definição de mobiliário. No projeto do UNA, por exemplo, há uma rígida grelha regular de $3 \times 3 \mathrm{~m}$, e em cada módulo são alocados os ambientes de acordo com sua funcionalidade, sendo utilizada uma estratégia de encaixe entre as unidades. A unidade de dois dormitórios utiliza cinco módulos, a de um dormitório quatro e a quitinete três. Em todas as unidades a cozinha e o banheiro ficam juntos em um mesmo quadrante, porém, essa solução cria um problema de privacidade, visto que a porta do banheiro se encontra no corredor para a cozinha sendo mais acessível pelo estar social, afastada dos dormitórios (Figura 9a).

Por sua vez, no projeto do Grupo SP são articulados módulos retangulares de 3,75 x 9m nos quais estão tanto os estares sociais quanto dormitórios e a estes são somados módulos hidráulicos menores. As unidades (quitinete, um ou dois dormitórios) se constituem de diferentes estratégias de encaixe dos módulos retangulares adicionados aos módulos hidráulicos, conforme Figura 9b. Os módulos hidráulicos estão separados e a cozinha se relaciona com o estar social enquanto o banheiro se liga ao dormitório porém essas relações se modificam em unidades com um dormitório - o banheiro se relaciona com o estar social também - e em unidades de dois dormitórios - o banheiro se relaciona com o segundo dormitório gerando problemas de privacidade. As propostas utilizam as paredes para compartimentação dos estares, todavia, em ambos os projetos ocorrem situações em que a definição espacial ocorre através de mobiliário, como nas unidades quitinete das duas propostas e nas unidades de dois dormitórios do Grupo SP - nas quais os armários delimitam o espaço entre estar social e dormitório. As unidades não possuem flexibilidade das divisórias ou possibilidade de ampliação. A adaptabilidade em caso de crescimento da família é praticamente nula, sendo necessário a adaptação para dormitório de parte do espaço do estar social.

Figura 7: Condicionantes Ambientais e Tipologia Habitacional.
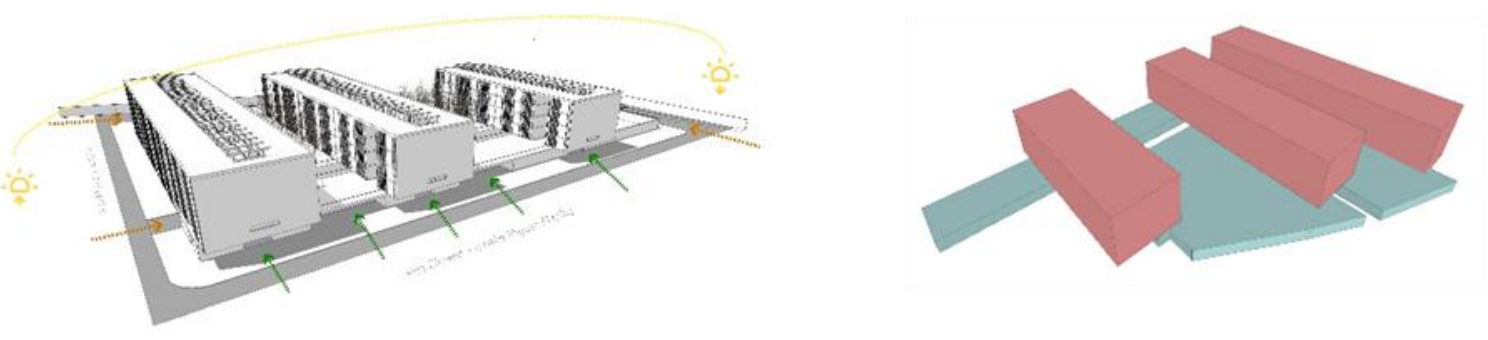

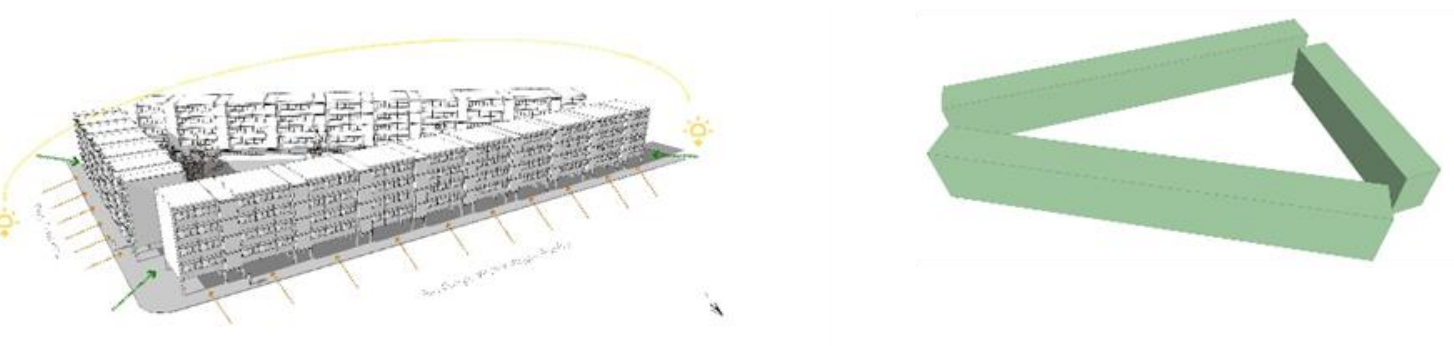

Figura 8: Quadro comparativo entre unidades habitacionais - Circulação vertical.

8(a) HabitaSampa - UMA 8(b) HabitaSampa - Grupo SP

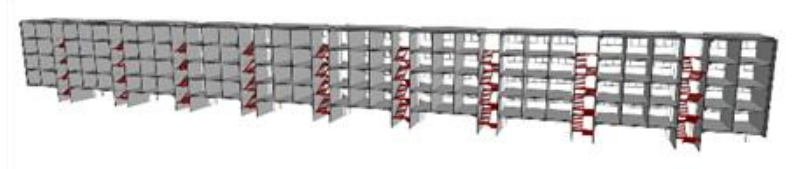

Fonte: Esquema Gráfico: Redesenho e Diagramas produzidos pelos autores.

Figura 9: Quadro comparativo entre unidades habitacionais - Arranjo Espacial UNA/Grupo SP.

9(a) HabitaSampa - UNA

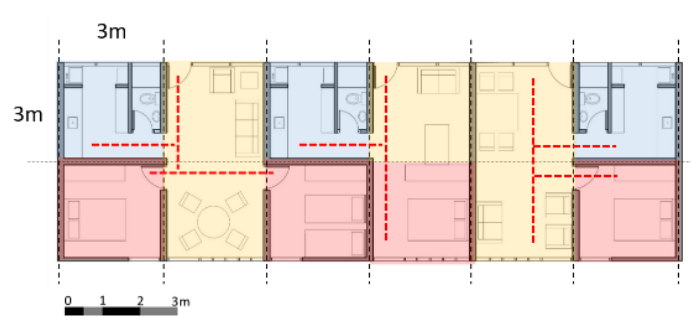

9(b) HabitaSampa - Grupo SP

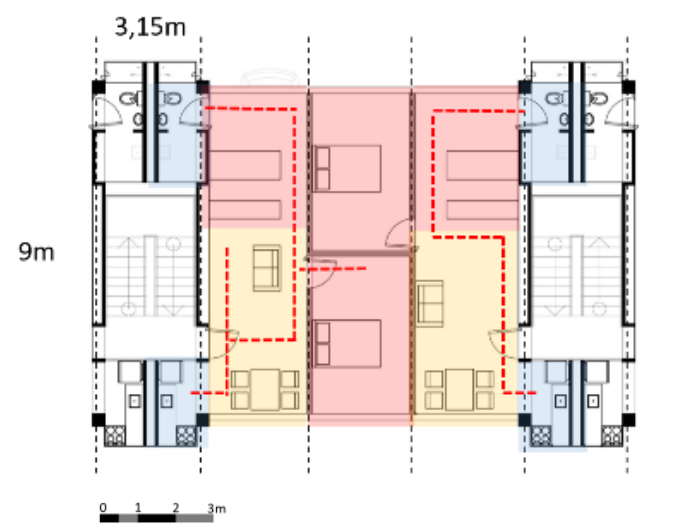

Fonte Figuras 7, 8 e 9: Esquema Gráfico: Redesenhos, Diagramas produzidos pelos autores.

\section{CONSIDERAÇÕES FINAIS: INTERAÇÃO HABITAÇÃO SOCIAL E CIDADE}

A instrumentalização da pesquisa pode ser sintetizada na Tabela 2, na qual a primeira coluna apresenta 0 conjunto residencial que está sendo analisado, a segunda coluna refere-se ao edifício e a unidade habitacional representando o senso de habitabilidade, e a terceira e última coluna se refere a implantação do conjunto no contexto urbano representando o senso de urbanidade. Ela sintetiza as análises dos conjuntos habitacionais, comparando-os dentro de uma escala de possibilidades de desempenho de cada uma das categorias dos sensos de urbanidade e habitabilidade, do mais positivo ao mais negativo. O senso de habitabilidade foi analisado a partir do redesenho das plantas baixas, cortes, fachadas e geração de 3D virtuais, e as categorias que representam o senso de urbanidade foram realizadas a partir da construção de percursos virtuais em 3D. Os percursos seguem alguns princípios das análises físico virtuais, tendo início dentro das unidades habitacionais e finaliza-se no espaço público aberto, na cidade. O percurso de cada conjunto habitacional possui estações fixas que devem ser obrigatoriamente interligados, são elas: estação de partida - estar da unidade; estação saída da unidade habitacional e área condominial - porta de entrada da unidade habitacional; estação dentro do espaço condominial - coberto e aberto; estação espaço condominial e espaço público aberto - porta de entrada do conjunto habitacional. 
Tabela 2: Síntese da Análise Comparativa.

\begin{tabular}{|c|c|c|}
\hline $\begin{array}{c}\text { Nome do Conjunto } \\
\text { HIS }\end{array}$ & Senso de Habitabilidade & Senso de Urbanidade \\
\hline $\begin{array}{l}\text { Ipê Amarelo - Arquitetos } \\
\text { Associados }\end{array}$ & $\begin{array}{l}\text { harmonia espacial (-) } \\
\text { conforto ambiental e privacidade }(+) \\
\text { sentido de lar }(+) \\
\text { opções e flexibilidade }(-)\end{array}$ & $\begin{array}{l}\text { sensibilidade ambiente construído/natural }(+) \\
\text { conectividade, legibilidade e sustentabilidade social (-) } \\
\text { identidade }(+)\end{array}$ \\
\hline Box House - Yuri Vital & $\begin{array}{l}\text { harmonia espacial (-) } \\
\text { conforto ambiental e privacidade }(+) \\
\text { sentido de lar }(+) \\
\text { opções e flexibilidade }(-)\end{array}$ & $\begin{array}{l}\text { sensibilidade ambiente construído/natural }(+) \\
\text { conectividade, legibilidade e sustentabilidade social }(-) \\
\text { identidade }(+)\end{array}$ \\
\hline Habita Sampa - UNA & $\begin{array}{l}\text { harmonia espacial }(+) \\
\text { conforto ambiental e privacidade }(+) \\
\text { sentido de lar }(+) \\
\text { opções e flexibilidade }(-)\end{array}$ & $\begin{array}{l}\text { sensibilidade ambiente construído/natural }(+) \\
\text { conectividade, legibilidade e sustentabilidade social }(+) \\
\text { identidade }(+)\end{array}$ \\
\hline Habita Sampa - Grupo SP & $\begin{array}{l}\text { harmonia espacial }(+) \\
\text { conforto ambiental e privacidade }(-) \\
\text { sentido de lar }(+) \\
\text { opções e flexibilidade }(-)\end{array}$ & $\begin{array}{l}\text { sensibilidade ambiente construido/natural }(-) \\
\text { conectividade, legibilidade e sustentabilidade social }(+) \\
\text { identidade }(-)\end{array}$ \\
\hline
\end{tabular}

Fonte: Esquema Gráfico: Redesenhos, Diagramas produzidos pelos autores.

A técnica de análise dos projetos sobre o redesenho e a construção dos percursos no 3D permitem o desenvolvimento da crítica em arquitetura, uma vez que desenvolvem a leitura dos códigos de representação, a identificação de padrões formais e funcionais, a relação entre a bi e a tridimensionalidade, o reconhecimento das relações formais com a configuração do espaço. Além disso, a percepção virtual possibilitada pelos percursos tridimensionais (Figuras 10a e 10b), somada ao embasamento em conceitos investigados através de bibliografia específica possibilitam um maior entendimento sobre a relação do usuário com o espaço, a relação do usuário com o lugar. Especialmente por serem referenciadas no ponto de vista do observador, oferecem uma compreensão sobre a interação entre a escala do usuário com a escala do edifício, e suas possibilidades de apropriação do espaço, tanto privado - na unidade habitacional quanto do público e suas derivações - circulação entre unidades, espaços condominiais, rua pública e ruas internas.

A partir dessa investigação, nota-se como recorrente a estratégia de condomínios de tipologia horizontal inseridos como ilhas na cidade, não no sentido de autossuficiência de infraestrutura, mas de fechamento para o interior do lote. O perímetro murado, a pouca permeabilidade do conjunto em relação à rua e a transição não gradual de privacidade se mostram como sensos de urbanidade que valorizam antes o individual do que o sentido coletivo. Os conjuntos habitacionais para o HabitaSampa, em grande contraste aos condomínios de tipologia horizontal, demonstram maior preocupação com a permeabilidade entre o espaço público e as áreas condominiais apesar de não se inserirem no tecido urbano e não manterem conexão com a escala do entorno. Também é notável nas propostas a criação de um gradiente de privacidade e espaços externos positivos que promovem o coletivo sobre o individual. Nestas propostas, apesar da ausência de flexibilidade, a diversidade de usuários se mostra maior do que nas tipologias horizontais devido à variedade de unidades habitacionais. Em contrapartida, os condomínios horizontais apresentam como padrão positivo a possibilidade - mesmo que restrita - de flexibilização espacial. Dessa forma, é possível inferir que a distinção de tipologias proporciona a abstração de diferentes formas de apropriação de lugar: ora por maior conexão com o espaço aberto, ora por maior versatilidade no arranjo íntimo do habitar. 
Constantinou, E; Machado, L. B; Rodrigues, A. L.

Figura 10a: Percursos - comparativo entre tipologias horizontais: Ipê Amarelo/Box House (da esquerda para a direita).
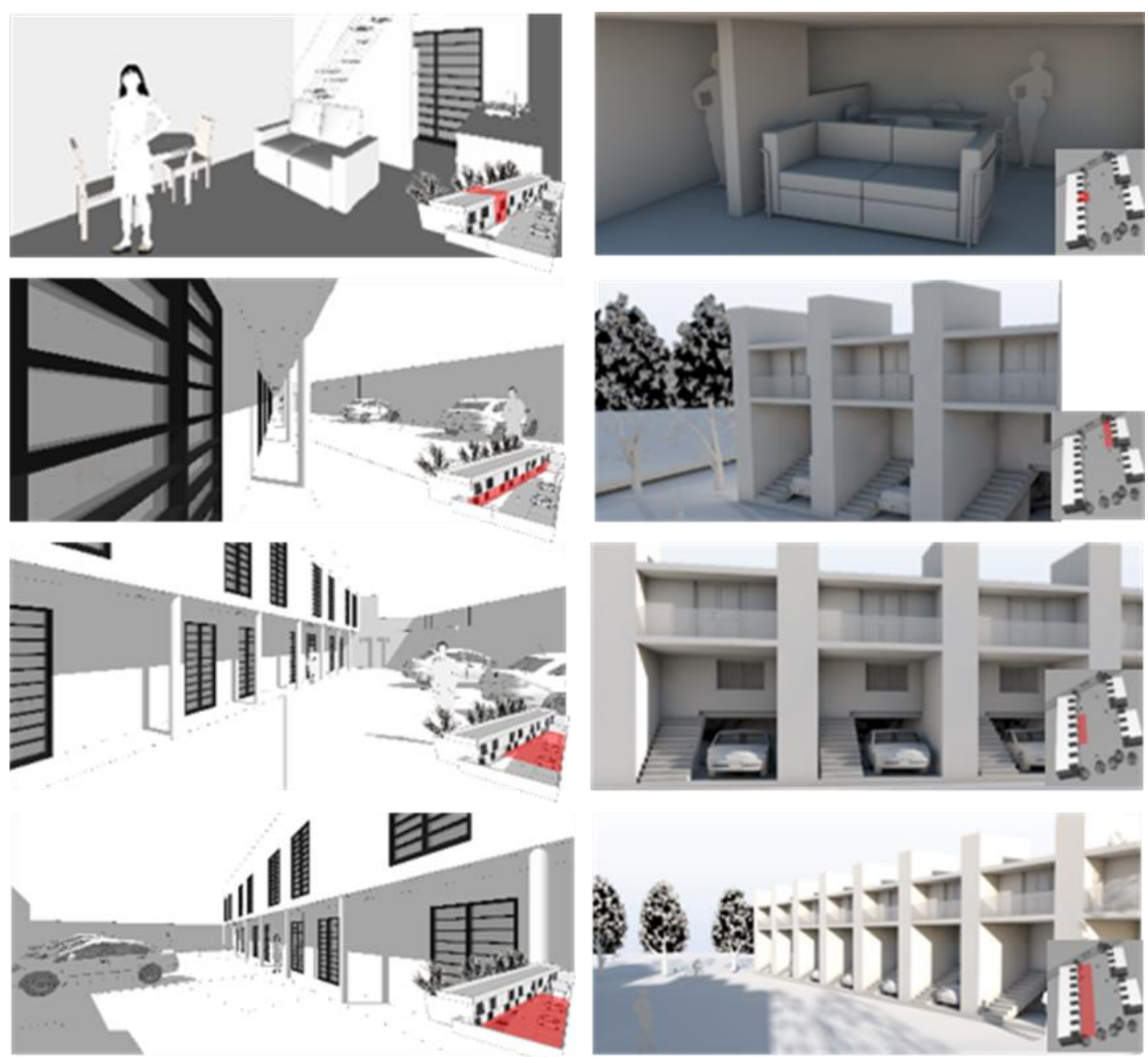
Figura 10b: Percursos - comparativo entre tipologias verticais: UNA/Grupo SP (da esquerda para a direita).
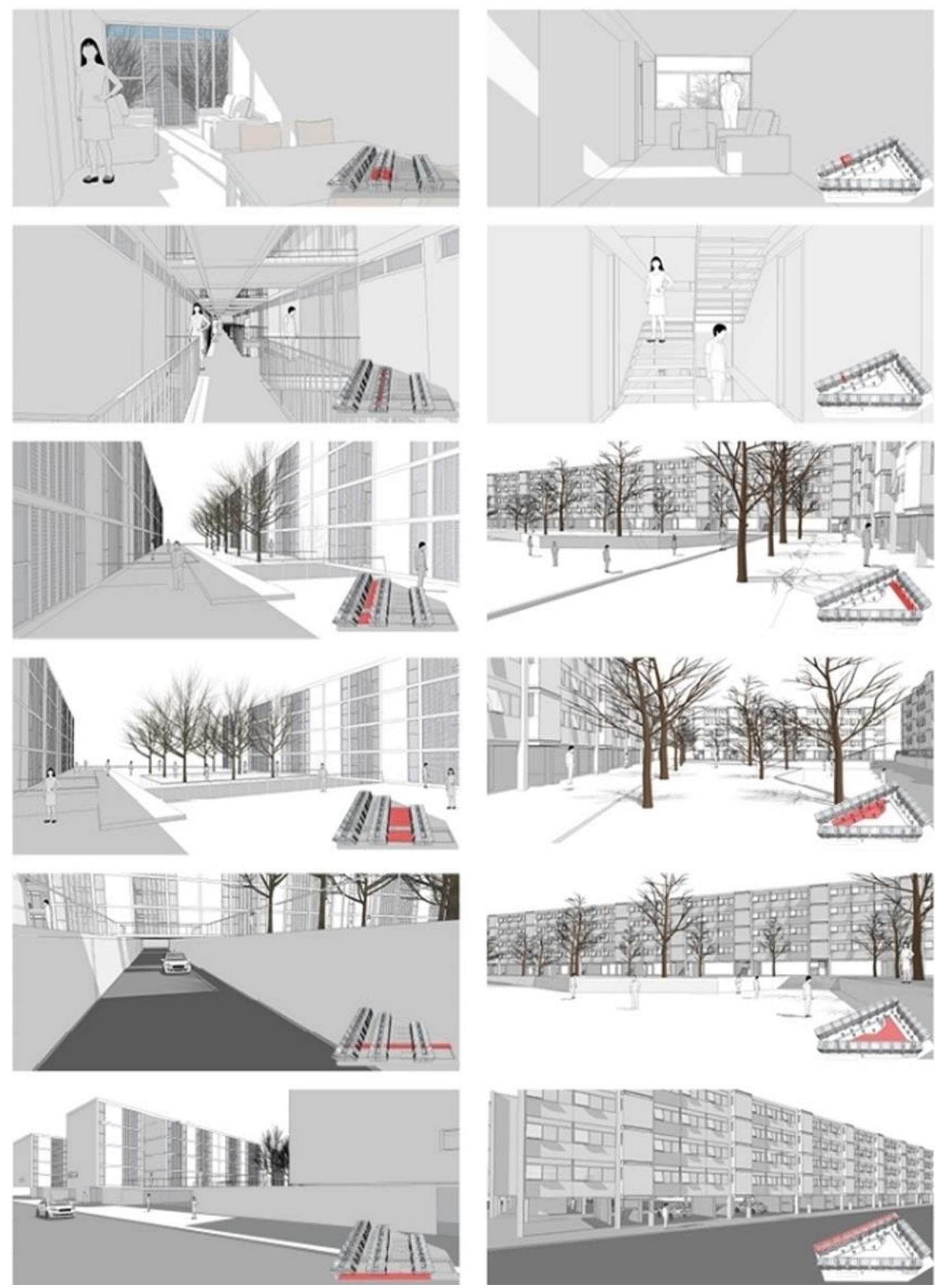

Fonte: Esquema Gráfico: 3D e Diagramas produzidos a partir de Redesenhos dos autores. 


\section{REFERÊNCIAS BIBLIOGRÁFICAS}

AGUIAR, D. V.; NETTO, V. M..; HOLANDA, F. B. Urbanidades. Rio de Janeiro: Folio Digital / Letra e Imagem, 2012.

BARROS, R. R. M. P.; PINA, S. A. M. G. A; Humanização no projeto da habitação coletiva. In: KOWALTOWSKI, D. K.; MOREIRA, D. C.; PETRECHE, J. R. D.; FABRÍCIO, M. M. O processo de projeto em arquitetura: da teoria a tecnologia, Campinas, SP: Oficina de Textos, pp.245-272, 2011.

BONDUKI, N. Os pioneiros da habitação social - cem anos de política pública no Brasil. V.1, São Paulo: Ed SESCUNESP, 2014.

BONDUKI, Nabil. Origens da habitação social no Brasil. Tese de doutorado, São Paulo: FAUUSP, 2003.

CASTELLO, Lineu. O lugar geneticamente modificado. ArqTexto (UFRGS), V.9,P.76-91,2006.

CASTELLO, Lineu (Org). Lugares de Urbanidade.1.ed. Curitiba,PR.Ed.CRV,2017.

CONCURSO HABITASAMPA. Projetos para Locação Social. São Paulo, Vitruvius, ano 04, n. 040.02, abr/2004. Disponível em: <http://www.vitruvius.com.br/revistas/read/projetos/04.040/2290>. Acessado 12/Dez/2015.

CULLEN, Gordon. Paisagem urbana. (col. Arquitectura \& Urbanismo,1). Lisboa: Edições 70, 2006.

D’AMICO, F. O programa MCMV e a Caixa Econômica Federal. In: 1ํConcurso Nacional de Monografias: a Caixa e o Desenvolvimento Econômico Brasileiro. Centro Celso Furtado de Políticas para o desenvolvimento, 2010.

GEHL, J. Cidades para Pessoas. São Paulo: Perspectiva, 2013

GRUPO SP. Habita Sampa - Conjunto Cônego Vicente Marino. Disponível em: http://www.gruposp.arq.br/?p=563. Acessado em: 15 julho 2015

JACOBS, J. Morte e Vida de Grandes Cidades. São Paulo: Martins Fontes, 2000. (Original de 1961).

KOURY, A.P.; BONDUKI, N.G.; MANOEL, S.K. Analise Tipológica da Produção Habitacional Econômica no Brasil: 1930-1964.In: 5o SEMINÁRIO DOCOMOMO-BRASIL. Anais do 5o Seminário Docomomo Brasil - São Carlos Arquitetura e Urbanismo Modernos: Projeto e Preservação. São Carlos: DOCOMOMO, 2013. Disponível em: <http://www.docomomo. org.br/seminários \%205\%20S\% 20Carlos\%20 sumario \%20trabalhos.htm>. Acessado em: 20/Out/2016

MARICATO, E. As ideias fora do lugar e o lugar fora das ideias. In: MARICATO, E.; VAINER, C.; ARANTES, O. A cidade do pensamento único: desmanchando consensos. Petrópolis: Vozes, 2002.

PANERAI, P.; CASTEX, J.; DEPAULE, J. C. Formes urbaines : de l'îlot à la barre. Marseille: Parenthèses, 2009.

RAMOS, F. G. V.. Redesenho - conceitos gerais para compreender uma prática de pesquisa histórica em arquitetura. Vitruvius - Arquitextos, São Paulo, ano 17, n. 195.09, ago. 2016. Disponível em: <http://www.vitruvius.com.br/revistas/read/arquitextos/17.195/6181>. Acessado em: 20/Out/2016.

SANVITTO, M. L. A. Habitação Coletiva econômica na arquitetura moderna brasileira entre 1964 e 1986 .Tese (Doutorado em Arquitetura). PROPAR/UFRGS, Porto Alegre, 2010.

\section{NOTA}

Registramos nosso agradecimento à estudante Flavia Blanco Tissot, graduanda do Curso de Arquitetura e Urbanismo da UFRGS que, na condição de membro do grupo de pesquisa, colaborou com a realização deste artigo por meio de redesenhos e diagramas do projeto Box House.

NOTA DO EDITOR (*) O conteúdo do artigo e as imagens nele publicadas são de responsabilidade do(s) autor(es). 